\title{
Intestinal Region-Specific and Layer-Dependent Induction of TNF $\alpha$ in Rats with Streptozotocin-Induced Diabetes and after Insulin Replacement
}

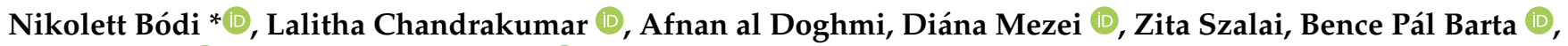 \\ János Balázs (1) and Mária Bagyánszki (1)
}

Department of Physiology, Anatomy and Neuroscience, Faculty of Science and Informatics, University of Szeged, Közép fasor 52, H-6726 Szeged, Hungary; lalitha.biochem87@gmail.com (L.C.); afnanaldoghmi1217@gmail.com (A.a.D.); mezei.diana@bio.u-szeged.hu (D.M.); zszalai@bio.u-szeged.hu (Z.S.); bbencep96@gmail.com (B.P.B.); jbalazs@bio.u-szeged.hu (J.B.); bmarcsi@bio.u-szeged.hu (M.B.)

* Correspondence: bodi.nikolett@bio.u-szeged.hu; Tel.: +36-62-544143

check for updates

Citation: Bódi, N.; Chandrakumar, L.; al Doghmi, A.; Mezei, D.; Szalai, Z.; Barta, B.P.; Balázs, J.; Bagyánszki, M. Intestinal Region-Specific and Layer-Dependent Induction of TNF $\alpha$ in Rats with Streptozotocin-Induced Diabetes and after Insulin Replacement. Cells 2021, 10, 2410. https://doi.org/ $10.3390 /$ cells 10092410

Academic Editors: In-Kyu Lee and Dipanjan Chanda

Received: 24 July 2021

Accepted: 10 September 2021

Published: 13 September 2021

Publisher's Note: MDPI stays neutral with regard to jurisdictional claims in published maps and institutional affiliations.

Copyright: (c) 2021 by the authors. Licensee MDPI, Basel, Switzerland. This article is an open access article distributed under the terms and conditions of the Creative Commons Attribution (CC BY) license (https:/ / creativecommons.org/licenses/by/ $4.0 /)$.

\begin{abstract}
Tumour necrosis factor alpha $(\mathrm{TNF} \alpha)$ is essential in neuroinflammatory modulation. Therefore, the goal of this study is to reveal the effects of chronic hyperglycaemia and insulin treatment on $\mathrm{TNF} \alpha$ expression in different gut segments and intestinal wall layers. TNF $\alpha$ expression was mapped by fluorescent immunohistochemistry and quantitative immunogold electron microscopy in myenteric ganglia of duodenum, ileum and colon. Tissue TNF $\alpha$ levels were measured by enzymelinked immunosorbent assays in muscle/myenteric plexus-containing (MUSCLE-MP) and mucosa/submucosa/submucous plexus-containing (MUC-SUBMUC-SP) homogenates. Increasing density of TNF $\alpha$-labelling gold particles is observed in myenteric ganglia from proximal to distal segments and TNF $\alpha$ tissue levels are much more elevated in MUSCLE-MP homogenates than in MUC-SUBMUC-SP samples in healthy controls. In the diabetics, the number of TNF $\alpha$ gold labels is significantly increased in the duodenum, decreased in the colon and remained unchanged in the ileal ganglia, while insulin does not prevent these diabetes-related TNF $\alpha$ changes. TNF $\alpha$ tissue concentration is also increased in MUSCLE-MP homogenates of diabetic duodenum, while decreased in MUC-SUBMUC-SP samples of diabetic ileum and colon. These findings support that type 1 diabetes has region-specific and intestinal layer-dependent effects on TNF $\alpha$ expression, contributing to the regional damage of myenteric neurons and their intestinal milieu.
\end{abstract}

Keywords: tumour necrosis factor alpha; cytokine; myenteric neurons; neuronal environment; duodenum; ileum; colon; diabetes; insulin

\section{Introduction}

Distinct structure and function as well as genetic and developmental features fundamentally define the appropriate intestinal milieu in the small and large intestine and even in their subregions [1,2], and pathological stimuli differently affect this regional molecular environment. Among others, type 1 diabetes has strictly region-specific effects on the microbial composition [3,4], antioxidant defence or oxidative status [5] of different gut segments. These all contribute to region-dependent nitrergic enteric neuropathy [6,7], that is markedly involved in gut motility disturbances $[6,8,9]$ suffered by diabetic patients worldwide.

The host-microbial interactions have an essential role in starting avalanche-like events, including epithelial barrier functions, intestinal immune cell activation and neuro-immune crosstalk [10]. The neuro-immune interactions have prominent effects on regulating the severity of inflammatory processes [11] in all layers of the gut wall.

Among the key players, tumour necrosis factor alpha $(\mathrm{TNF} \alpha)$ has a great impact on the maintenance of intestinal homeostasis under physiological conditions and the dysregulation of TNF signalling may accompany several diseases [12]. The TNF superfamily contains 
19 ligands and 29 receptors belonging to transmembrane proteins and characterized by a conserved TNF homology domain at the C-terminal [13]. The two types of TNF proteins, $\mathrm{TNF} \alpha$ and TNF $\beta$, have more than $50 \%$ of sequence homology [14]. TNF $\alpha$ functions as a cytokine and is expressed mainly by immune cells, macrophages [15], but also by neurons in the central or enteric nervous system [16-18]. It can bind to two different receptors (TNFR1 and TNFR2) and regulates several cell functions, such as inflammation, immune response during infection, cell proliferation, differentiation or apoptosis [12,19]. After its release, $\mathrm{TNF} \alpha$ can enhance the production of other inflammatory cytokines from other cells; therefore, it is primary featured as a powerful pro-inflammatory cytokine [12].

The TNF $\alpha$-induced enhancement of oxidative stress as well as the consequent neuroinflammatory processes can promote neurodegeneration via different cellular pathways [20]. Nitric oxide-enhanced TNF $\alpha$-induced neurotoxicity through a suppression of nuclear factor- $\kappa \mathrm{B}$ has been observed in retinal neurons [21]. An increased level of TNF $\alpha$ released from activated microglia and astrocytes has been revealed in the affected areas in different central nervous system neurodegenerative diseases [20,22]. The role of an increased $\mathrm{TNF} \alpha$ level associated with caspase activation and elevated inducible nitric oxide synthase expression in spinal cord injuries has also been observed in neuronal cell death $[23,24]$. Additionally, the blockade of $\mathrm{TNF} \alpha$ signalling has been in the focus of therapy in many autoimmune diseases such as rheumatoid arthritis or Crohn's disease [25].

In type 1 diabetic patients, the serum level of $\mathrm{TNF} \alpha$ was increased compared to controls [26]. Additionally, elevated plasma TNF $\alpha$ levels correlating with different metabolic parameters have also been revealed [27]. TNF $\alpha$ directly affects insulin signalling and, thus, has a role in the development of insulin resistance and obesity [28-30]. TNF $\alpha$ concentration was enhanced even in tear fluids, which correlated well with the severity of diabetic retinopathy [31]. Increased TNF $\alpha$ levels have been related to the development of diabetic nephropathy involving reactive oxygen species accumulation and related cytotoxicity in kidney cells [32-34]), while TNF $\alpha$ inhibition ameliorated the glomerular and tubular injury in diabetic kidney [35]. TNF $\alpha$ is directly involved in the destruction of $\beta$-cells in isolated islets [36] and plays a key role in the onset of diabetes in mice through the regulation of dendritic cell maturation and activation of islet-specific pancreatic T-cells [37].

The primary goal of the present study is to evaluate the intestinal region-dependent effects of chronic hyperglycaemia and immediate insulin treatment on TNF $\alpha$ expression in myenteric ganglia of different gut segments. Furthermore, we aim to reveal the possible differences in TNF $\alpha$ expression in different layers of the gut wall.

\section{Materials and Methods}

\subsection{Animal Model}

Adult male Wistar rats (Crl:WI BR; Toxi-Coop Zrt., Balatonfüred, Hungary) weighing 210-260 g, kept on standard laboratory chow (Farmer-Mix Kft., Zsámbék, Hungary) and with free access to drinking water, were used throughout the experiments. The rats were divided randomly into three groups: STZ-induced diabetics (diabetics; $n=5$ ), insulin-treated STZ-induced diabetics (insulin-treated diabetics; $n=4$ ) and sex- and age-matched controls $(n=5)$. Hyperglycaemia was induced as described previously [6,38-40]. The animals were considered diabetic if the non-fasting blood glucose concentration was higher than $18 \mathrm{mM}$. From this time on, the insulin-treated group of hyperglycaemic rats received a subcutaneous injection of insulin (Humulin M3, Eli Lilly Nederland, Utrecht, The Netherlands) each morning (2 IU) and afternoon (2 IU). Equivalent volumes of saline were given subcutaneously to the diabetic and the control rats. The blood glucose level and weight of each animal were measured weekly. Those diabetic animals which recovered spontaneously, or their blood glucose level decreased under $18 \mathrm{mM}$ during the 10-week experimental period were excluded from the study. In all procedures involving experimental animals, the principles of the National Institutes of Health (Bethesda, MD, USA) guidelines and the EU directive 2010/63/EU for the protection of animals used for scientific purposes were strictly followed, and all the experiments were approved by the National Scientific Ethical 
Committee on Animal Experimentation (National Competent Authority), with the license number XX/1636/2019.

\subsection{Tissue Handling}

Ten weeks after the onset of hyperglycaemia, the animals were killed by cervical dislocation under chloral hydrate anaesthesia ( $375 \mathrm{mg} / \mathrm{kg}$ i.p.). The gut segments of diabetic, insulin-treated diabetic and control rats were dissected and rinsed in $0.05 \mathrm{M}$ phosphate buffer (PB; pH 7.4). Samples were taken from the duodenum ( $1 \mathrm{~cm}$ distal to the pylorus), the ileum ( $1 \mathrm{~cm}$ proximal to the ileo-caecal junction) and the proximal colon, and processed for fluorescent immunohistochemistry, quantitative electron microscopy and enzyme-linked immunosorbent assays (ELISA). For double-labelling fluorescent immunohistochemistry, samples $(2-3 \mathrm{~mm}$ ) from different gut segments were fixed in $4 \%$ paraformaldehyde and embedded in melted paraffin. For post-embedding electron microscopy, small pieces (2-3 mm) of the gut segments were fixed in $2 \%$ paraformaldehyde and $2 \%$ glutaraldehyde solution and then further fixed for $1 \mathrm{~h}$ in $1 \% \mathrm{OsO}_{4}$. After rinsing in buffer and dehydrating in increasing ethanol concentrations and acetone, they were embedded in Embed812 (Electron Microscopy Sciences, Hatfield, PA, USA). For the ELISA, the $3 \mathrm{~cm}$ long gut segments were cut along the mesentery and pinched flat. The layer of mucosa and submucosa containing the submucous plexus as well as the layers of intestinal smooth muscle layers, including the myenteric plexus, were snap-frozen in liquid nitrogen and stored at $-80^{\circ} \mathrm{C}$ until use.

\subsection{Fluorescent Immunohistochemistry}

For double-labelling immunohistochemistry, paraffin sections $(3.5 \mu \mathrm{m})$ derived from different gut segments were immunostained with TNF $\alpha$ and HuCD. Briefly, after blocking in tris(hydroxymethyl)aminomethane-buffered saline (TBS) containing $1 \%$ bovine serum albumin and $10 \%$ normal goat serum, the sections were incubated overnight with anti$\mathrm{TNF} \alpha$ (rabbit polyclonal IgG; ab6671, Figure S1, Abcam, Cambridge, UK; final dilution 1:50) and pan-neuronal anti-HuCD (mouse monoclonal IgG; A-21271, Invitrogen, Waltham, MA, USA; final dilution 1:50) primary antibodies at $4{ }^{\circ} \mathrm{C}$. After washing in TBS with $0.025 \%$ Triton X-100, sections were incubated with anti-rabbit Alexa Fluor 488 (Life Technologies Corporation, Molecular Probes, Inc., Waltham, MA, USA; final dilution 1:200) and $\mathrm{Cy}^{\mathrm{TM} 3}$ (Jackson ImmunoResearch Laboratories, Inc., West Grove, PA, USA; final dilution 1:200) secondary antibodies for $1 \mathrm{~h}$ at room temperature. Negative controls were performed by omitting the primary antibody when no immunoreactivity was observed (Figure S2). Sections were mounted on slides in Fluoromount ${ }^{\mathrm{TM}}$ Aqueous Mounting Medium (Sigma-Aldrich, Budapest, Hungary), observed and photographed with a ZEISS Imager Z.2 fluorescent microscope equipped with an Axiocam 506 mono camera.

\subsection{Quantitative Post-Embedding Immunohistochemistry}

Four embed blocks originated from each intestinal segment and condition were used to prepare ultrathin $(70 \mathrm{~nm})$ sections which were mounted on nickel grids and processed for TNF $\alpha$ immunogold labelling. Ultrathin sections (three grids per block) were incubated overnight in anti-TNF $\alpha$ rabbit polyclonal IgG (Abcam, UK; final dilution 1:25) primary antibody, followed by colloidal gold-conjugated anti-rabbit IgG (conjugated to $18 \mathrm{~nm}$ gold particles; Jackson ImmunoResearch, USA; final dilution 1:20) secondary antibody for $3 \mathrm{~h}$. The specificity of the immunoreaction was assessed in all cases by omitting the primary antibodies in the labelling protocol and incubating the sections only in the gold-conjugated secondary antibodies. Sections were counterstained with uranyl acetate (Merck, Darmstadt, Germany) and lead citrate (Merck, Germany), and were examined and photographed with a JEOL JEM 1400 transmission electron microscope. The quantitative features and the subcellular distributions of the gold particles labelling TNF $\alpha$ were determined in the myenteric ganglia. Fifty digital photographs of five myenteric ganglia per intestinal segment per condition were conducted at a magnification of 20,000× with the AnaySIS 3.2 
program (Soft Imaging System GmbH, Münster, Germany). The intensity of the labelling was expressed as the total number of gold particles per unit area.

\subsection{Measurement of Tissue TNF $\alpha$ Concentrations}

The intestinal tissue samples, including the layer of mucosa and submucosa with the submucous plexus (MUC-SUBMUC-SP) or the intestinal smooth muscle layers with the myenteric plexus in between (MUSCLE-MP), were frozen in liquid nitrogen, crushed into powder in a mortar and homogenized in $500 \mu \mathrm{L}$ homogenizing buffer $(100 \mu \mathrm{L}$ Protease Inhibitor Cocktail (Sigma-Aldrich, Hungary) in $20 \mathrm{~mL} 0.05 \mathrm{M} \mathrm{PB}$ ). Tissue homogenates were centrifuged at $5000 \mathrm{rpm}$ for $20 \mathrm{~min}$ at $4{ }^{\circ} \mathrm{C}$. The TNF $\alpha$ level of the intestinal tissue samples was determined by means of quantitative ELISA according to the manufacturer's instructions (SunRed Biotechnology, Shanghai, China). Optical density was measured at $450 \mathrm{~nm}$ (Benchmark Microplate Reader; Bio-Rad, Budapest, Hungary). The tissue TNF $\alpha$ concentrations were expressed as $\mathrm{pg} / \mathrm{mg}$ protein.

\subsection{Bradford Protein Micromethod for the Determination of Tissue Protein Content}

A commercial protein assay kit was used for the determination of protein content in tissue samples. Bradford reagent was added to each sample. After mixing and following $10 \mathrm{~min}$ incubation, the samples were assayed spectrophotometrically at $595 \mathrm{~nm}$. Protein level was expressed as $\mathrm{mg}$ protein/mL.

\subsection{Statistical Analysis}

Statistical analysis was performed with one-way analysis of variance (ANOVA) and Newman-Keuls test. All analyses were carried out with GraphPad Prism 6.0 (GraphPad Software, San Diego, CA, USA). A probability of $p<0.05$ was set as the level of significance. All data were expressed as means \pm SEM.

\section{Results}

\subsection{Disease Characteristics of Experimental Animals}

The general characteristics of the control, diabetic and insulin-treated diabetic rats at the end of the 10-week experimental period are shown in Table 1. The diabetic rats were characterized by a significantly increased blood glucose concentration $(24.19 \pm 0.61 \mathrm{mM})$ as compared to the age- and sex-matched controls $(5.81 \pm 0.22 \mathrm{mM})$. The immediate insulin treatment prevented the extremely high blood glucose level, which was close to the control level during the 10-week experimental period $(9.48 \pm 0.14 \mathrm{mM})$. The weight of the animals significantly increased in all groups during the experiment, but the final body weight of diabetic rats was less elevated compared to the control and the insulin-treated diabetic animals.

Table 1. Weight and glycaemic characteristics of the three experimental rat groups.

\begin{tabular}{|c|c|c|c|c|}
\hline & \multicolumn{2}{|c|}{$\begin{array}{l}\text { Body Weight } \\
\text { (g) } \pm \text { SEM }\end{array}$} & \multicolumn{2}{|c|}{$\begin{array}{l}\text { Blood Glucose Concentration } \\
(\mathrm{mmol} / \mathrm{L}) \pm \mathrm{SEM}\end{array}$} \\
\hline & Initial & Final & Initial & $\begin{array}{c}\text { Final } \\
\text { (Average) }\end{array}$ \\
\hline $\begin{array}{l}\text { Controls } \\
(n=5)\end{array}$ & $224.4 \pm 7.13$ & $504 \pm 15.65^{a}$ & $5.96 \pm 0.34$ & $5.81 \pm 0.22$ \\
\hline $\begin{array}{c}\text { Diabetics } \\
(n=5)\end{array}$ & $228.4 \pm 7.19$ & $373.4 \pm 12.51^{a b}$ & $6.2 \pm 0.25$ & $24.19 \pm 0.61^{a b}$ \\
\hline $\begin{array}{c}\text { Insulin-treated } \\
\text { diabetics } \\
(n=4)\end{array}$ & $251.5 \pm 4.35$ & $481.5 \pm 13.4^{\mathrm{ac}}$ & $6.65 \pm 0.18$ & $9.48 \pm 0.14^{\mathrm{abc}}$ \\
\hline
\end{tabular}




\subsection{Presence of $T N F \alpha$ Immunoreactivity in the Intestinal Sections}

Double-labelling fluorescent microscopy revealed TNF $\alpha$ immunoreactivity in myenteric ganglia and their environment (Figure 1). The fluorescent intensity varied in the different intestinal layers: it was clearly visible in the myenteric ganglia, low in the circular smooth muscle and pronouncedly intense in the longitudinal smooth muscle layer (Figure 1).
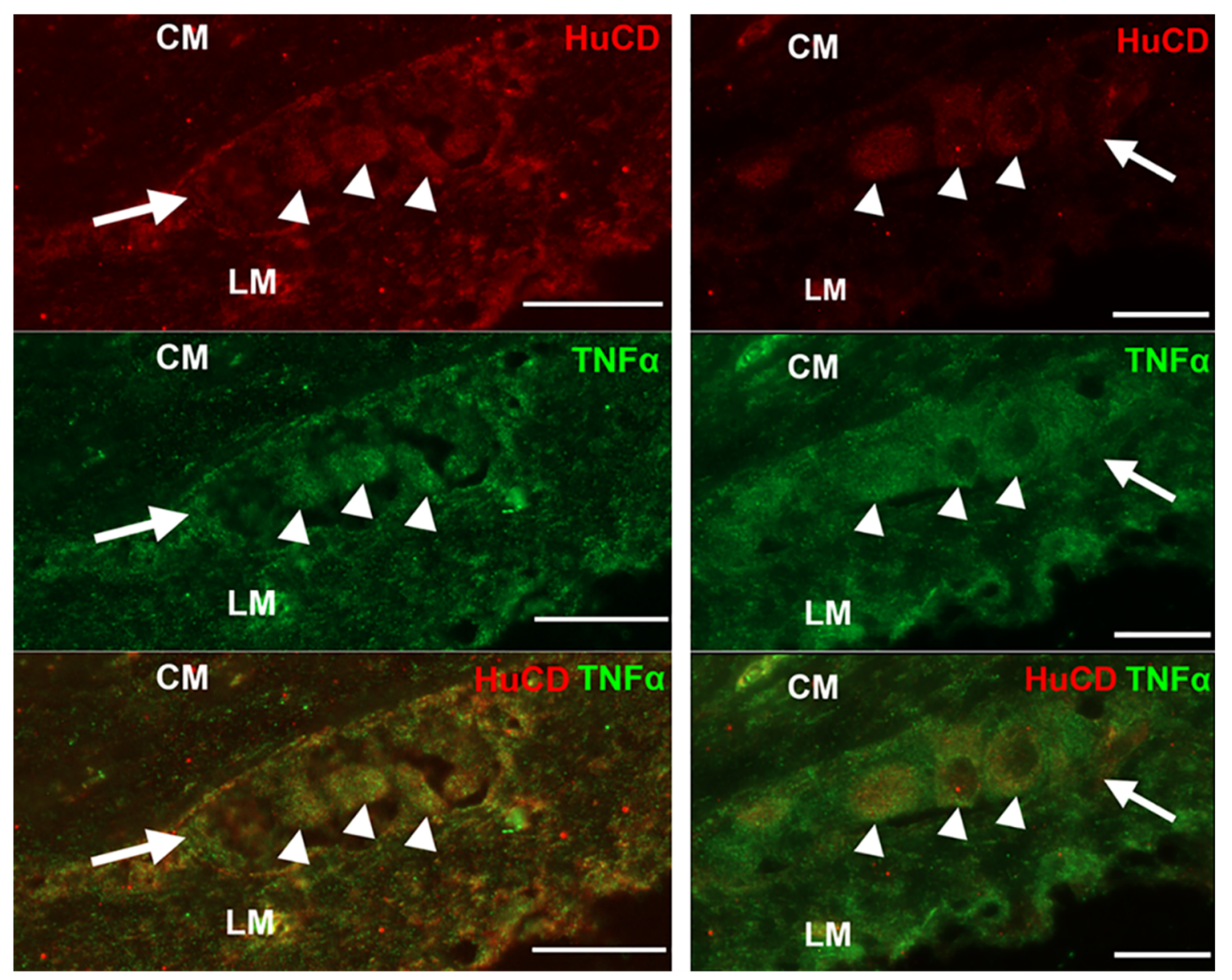

(a)

(b)

Figure 1. Representative fluorescent micrographs of paraffin sections of myenteric ganglia from the duodenum of a control (a) and diabetic (b) rat after TNF $\alpha$-HuCD double-labelling immunohistochemistry. LM-longitudinal smooth muscle layer; $\mathrm{CM}$ - circular smooth muscle layer; arrow-myenteric ganglia; arrowheads-myenteric neurons. Scale bar: $20 \mu \mathrm{m}$.

\subsection{Subcellular Localization and Quantification of TNF $\alpha$ Expression in Myenteric Ganglia}

The presence of TNF $\alpha$ was also confirmed by immunogold electron microscopy in myenteric ganglia (Figure 2). The majority of the $18 \mathrm{~nm}$ gold particles labelling TNF $\alpha$ were often located in groups at the plasma membrane or intracellular membranes, such as the mitochondria (Figure 2a) and cisternae of the rough endoplasmic reticulum (Figure 2b) or in the vicinity of synaptic vesicles (Figure 2c).

In control animals, the density of TNF $\alpha$-labelling gold particles was the lowest in the myenteric ganglia of the duodenum $(0.46 \pm 0.06)$. In the control ileum, the density of gold labels was more than twice $(1.08 \pm 0.22 ; p<0.01)$ and in the colon it was three times $(1.36 \pm 0.17 ; p<0.001)$ that of the duodenal segment (Figure 3$)$.

In the duodenal ganglia of diabetic rats, the number of TNF $\alpha$-labelling gold particles has nearly doubled relative to controls $(0.83 \pm 0.09$ vs. $0.46 \pm 0.06 ; p<0.01$; Figure 4$)$ and it was also elevated in insulin-treated rats $(0.91 \pm 0.13)$.

In the ileum of diabetics, the number of TNF $\alpha$ labels did not differ significantly from the control values; however, in insulin-treated rats it was reduced to half compared to the controls $(0.58 \pm 0.08$ vs. $1.08 \pm 0.22 ; p<0.05$; Figure 4$)$. 


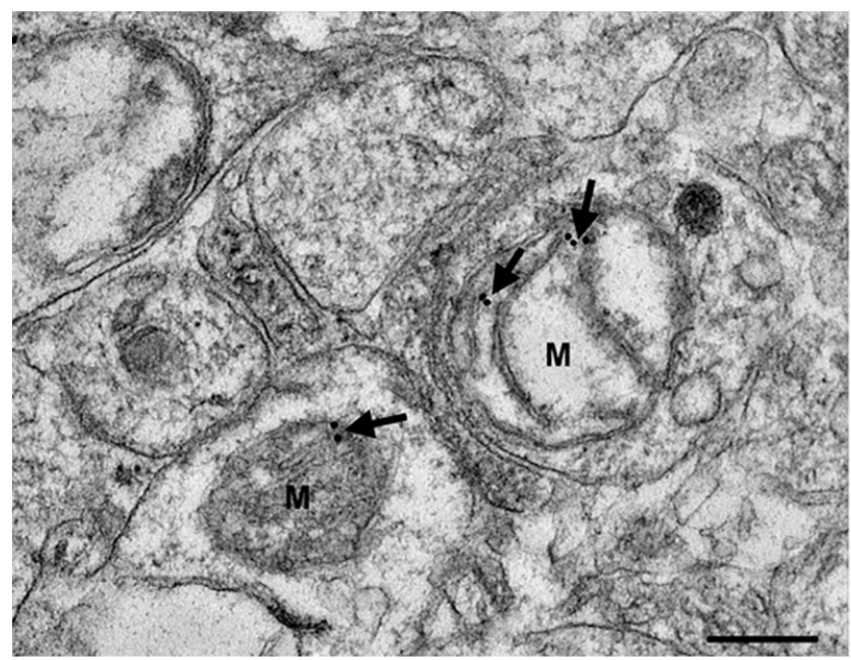

(a)

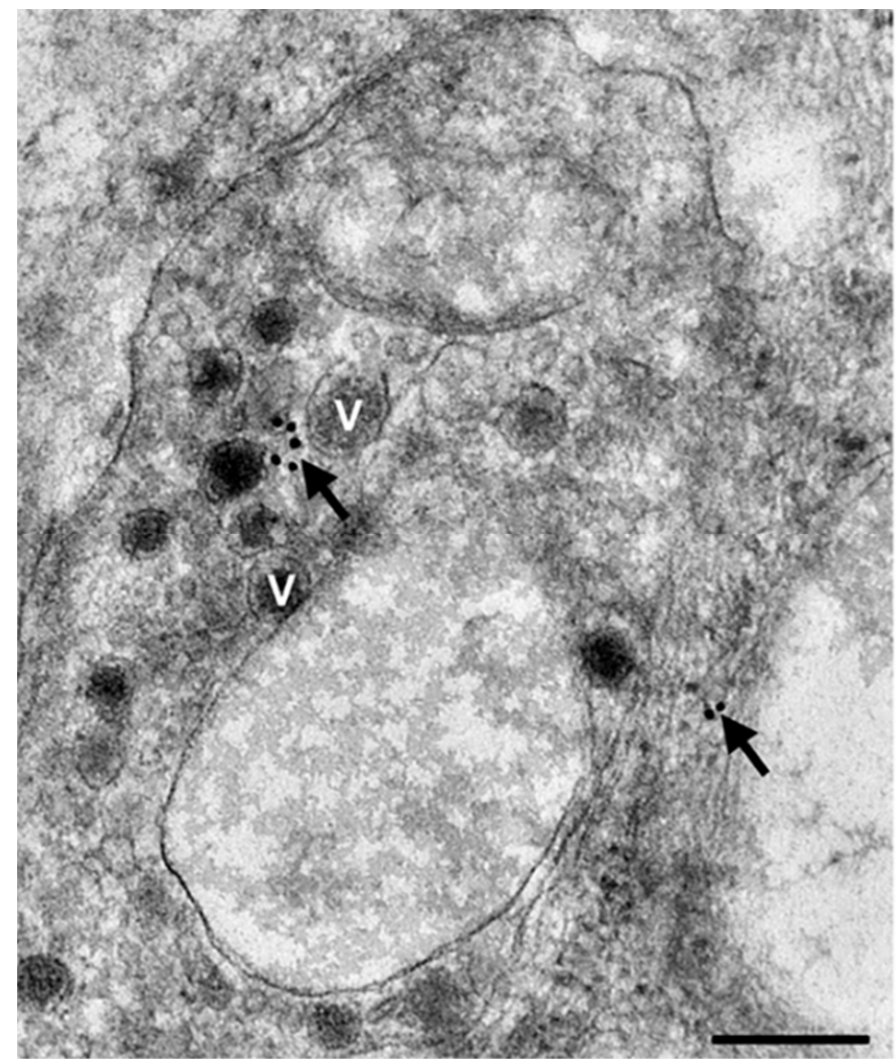

(c)

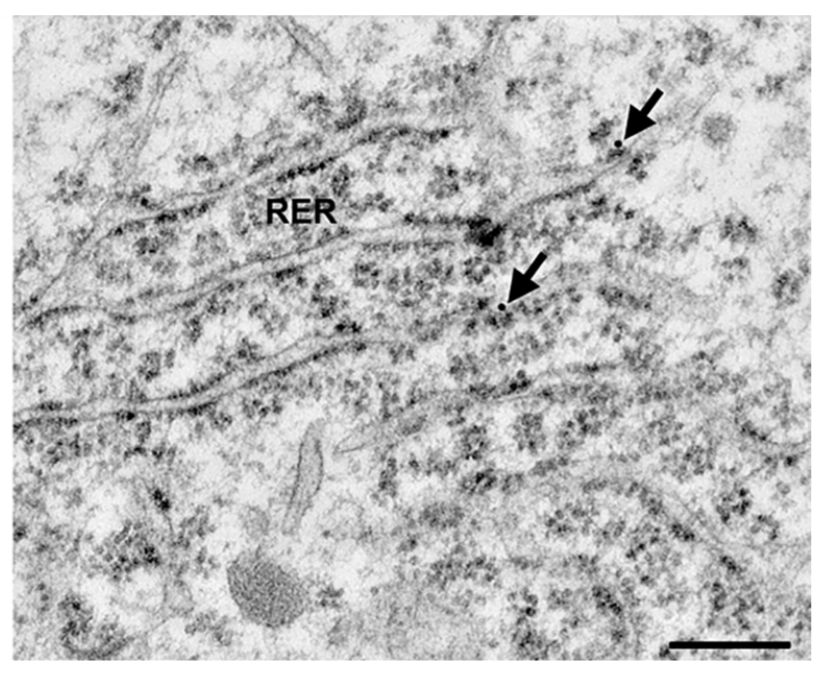

(b)

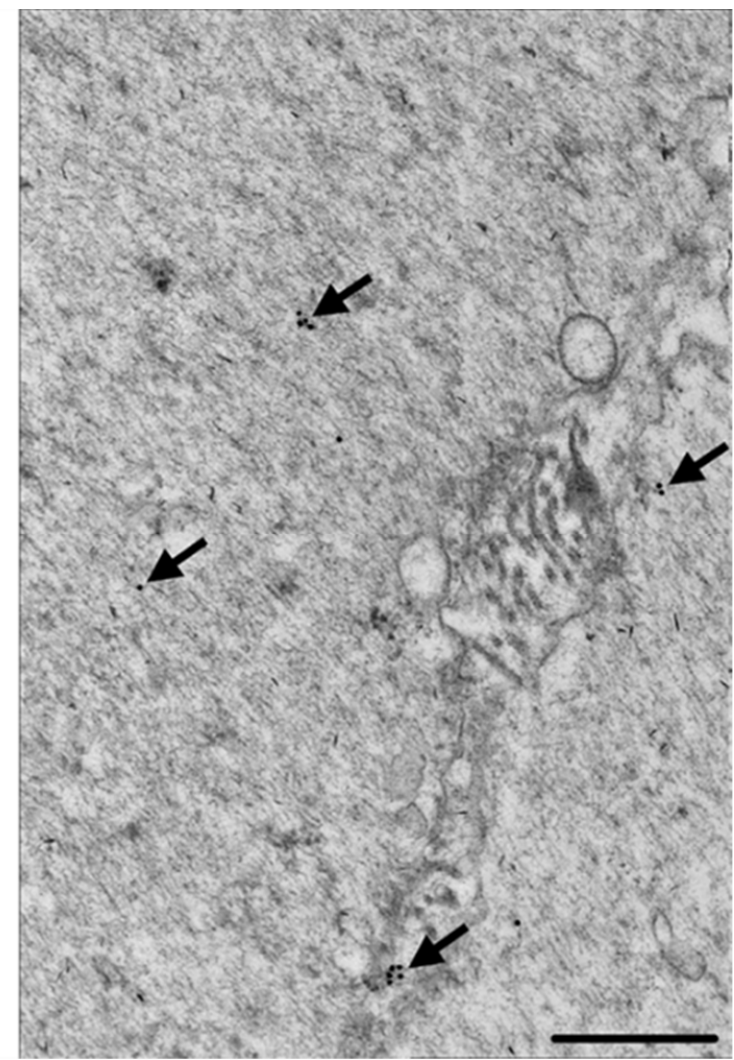

(d)

Figure 2. Representative electron micrographs of a portion of the ganglionic neuropil of the myenteric plexus in the duodenum (a) and the ileum (c) of a diabetic rat, a small detail of a perikaryon from the duodenum (b) of a diabetic rat and a part of longitudinal smooth muscle cells of intestinal wall from the colon (d) of a control rat after post-embedding immunohistochemistry, using a TNF $\alpha$-specific antibody. The majority of the $18 \mathrm{~nm}$ gold particles labelling TNF $\alpha$ (arrows) were grouped and attached to the plasma membrane or intracellular membranes, and they were observed also in the mitochondria (M) (arrows in (a)), in the vicinity of synaptic vesicles (V) (arrows in (b)) and at cisternae of the rough endoplasmic reticulum (RER) (arrows in (c)). Scale bars: $250 \mathrm{~nm}$. 


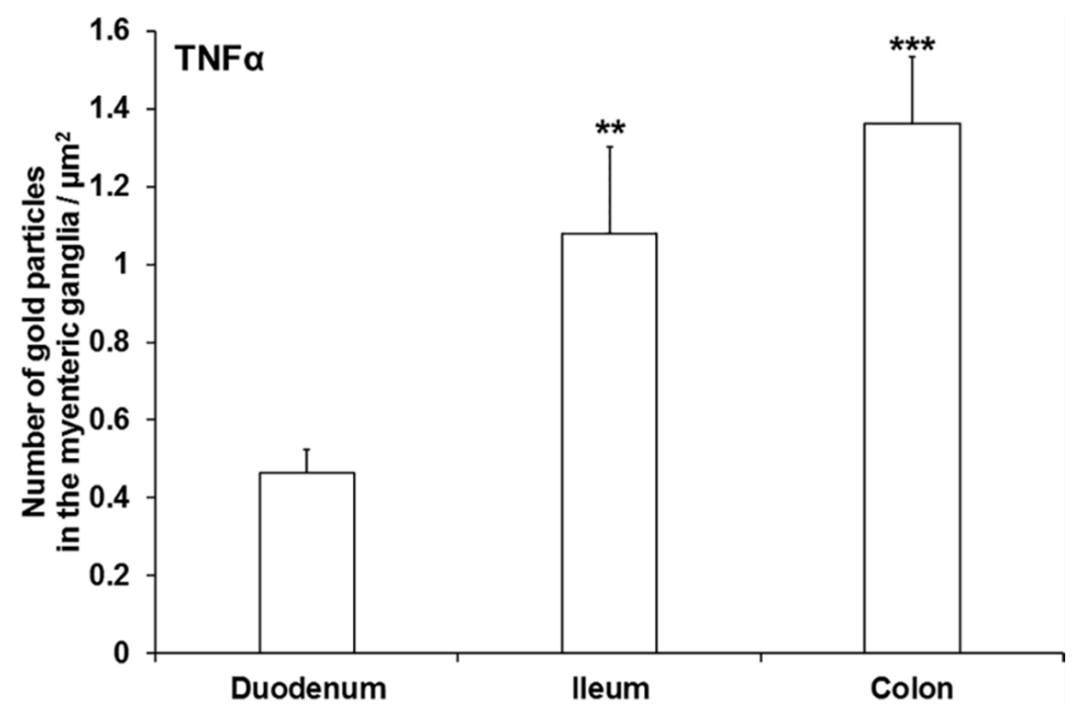

Figure 3. Quantitative evaluation of TNF $\alpha$-labelling gold particles in the myenteric ganglia from different gut segments of control rats. The numbers of gold particles increased from proximal to distal direction along the gut even in healthy animals. Data were expressed as means \pm SEM. ${ }^{* *} p<0.01$; *** $p<0.001$ (relative to the control duodenum).

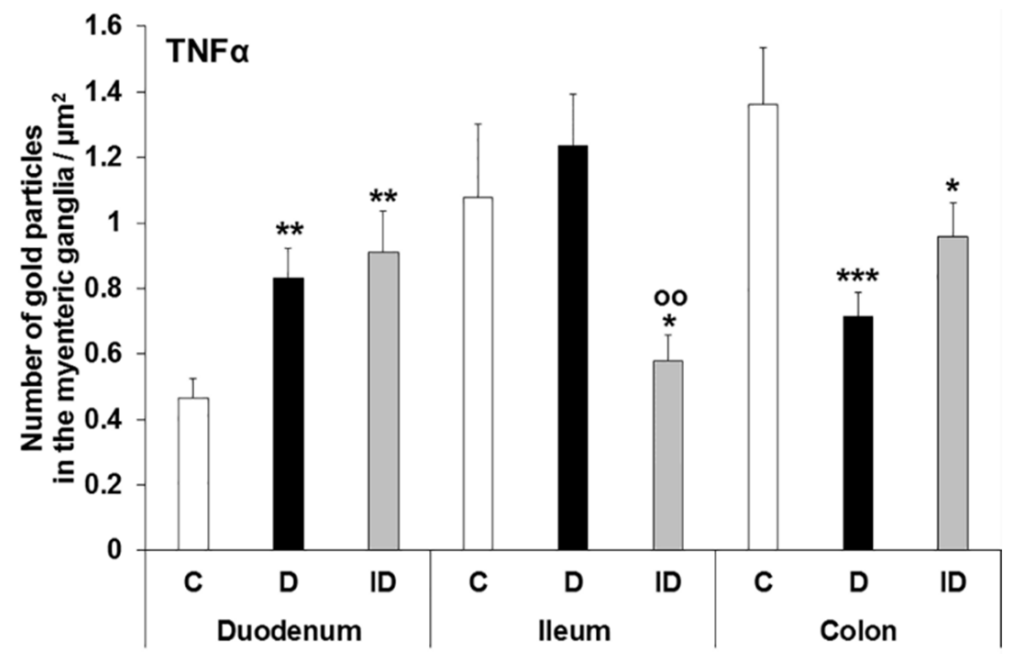

Figure 4. Quantitative evaluation of TNF $\alpha$-labelling gold particles in the myenteric ganglia from different gut segments of control, diabetic and insulin-treated diabetic rats. The number of TNF $\alpha-$ labelling gold particles increased in the duodenum, decreased in the colon and did not change in the ileum of diabetic rats. The immediate insulin replacement did not prevent the diabetes-related alterations. Data were expressed as means \pm SEM. ${ }^{*} p<0.05 ;{ }^{* *} p<0.01 ;{ }^{* *} p<0.001$ (relative to the controls), ${ }^{\text {oo }} p<0.01$ (between diabetics and insulin-treated diabetics). C-controls; D-diabetics; ID-insulin-treated diabetics.

\subsection{TNF $\alpha$ Levels in Different Intestinal Tissue Layers}

In healthy controls, the tissue level of TNF $\alpha$ varied on an extensive scale between the homogenates of different intestinal layers. While the TNF $\alpha$ protein level was $153.5-269.1 \mathrm{pg} / \mathrm{mg}$ in the tissue homogenates of MUSCLE-MP of different gut segments (Figure 5a), it was only $6.1-15.4 \mathrm{pg} / \mathrm{mg}$ in homogenates MUC-SUBMUC-SP of different intestinal regions (Figure $5 b$ ). The greatest difference was observed in the duodenum, where the TNF $\alpha$ level was 35-times higher in the MUSCLE-MP than in the MUC-SUBMUC-SP. Similarly, considerable differences were revealed in the other segments: the TNF $\alpha$ level was more than 17-times higher in the ileal and 10-times higher in the colonic MUSCLE-MP than in the MUC-SUBMUC-SP (Figure 5). 


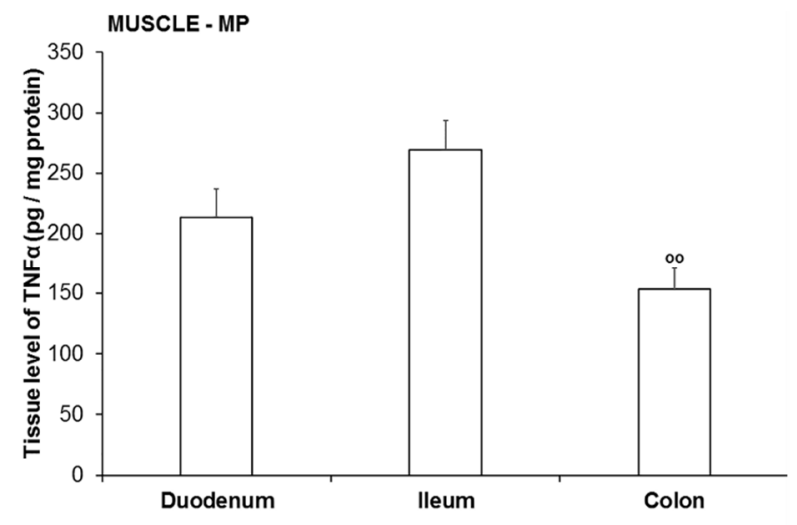

(a)

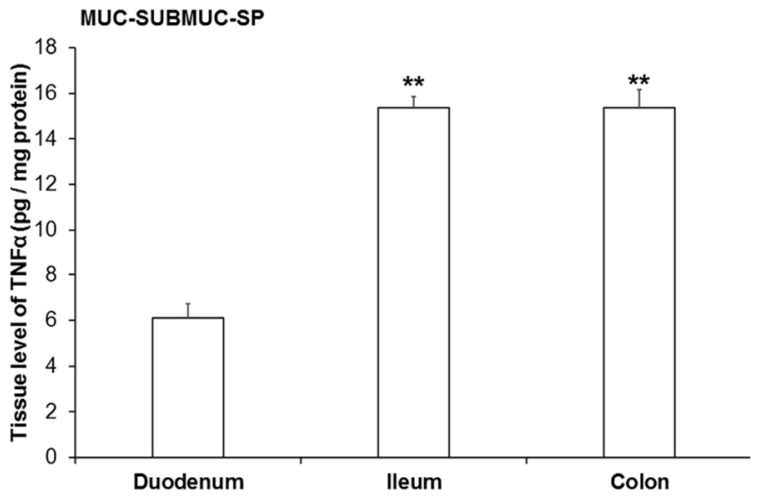

(b)

Figure 5. The tissue level of TNF $\alpha$ in the homogenates of intestinal smooth muscle layers, including the myenteric plexus (MUSCLE-MP) (a), as well as mucosa and submucosa, including submucous plexus (MUC-SUBMUC-SP) (b) from the different gut segments of controls. Data were expressed as means \pm SEM. ${ }^{* *} p<0.01$ (relative to the control duodenum), ${ }^{\text {oo }} p<0.01$ (between control ileum and colon).

In control rats, the tissue level of TNF $\alpha$ also varied along the gastrointestinal tract. In the case of MUSCLE-MP samples, it was the lowest in the colon and higher in the ileum $(p<0.01)$ and duodenum (Figure 5a). However, in the case of MUC-SUBMUC-SP samples, the TNF $\alpha$ level was the lowest in the duodenum and it was more than twice as high as in the ileum $(p<0.01)$ and colon $(p<0.01)$ (Figure 5b).

The effects of hyperglycaemia on TNF $\alpha$ expression were also strictly region-dependent. On the one hand, in MUSCLE-MP homogenates, the tissue level of TNF $\alpha$ increased significantly only in the duodenum of diabetics relative to controls (356.1 \pm 36.93 vs. $213.1 \pm 23.68$; $p<0.05)$; moreover, a further increase was observed in the insulin-treated diabetic group $(635.1 \pm 41.91 ; p<0.0001)$. In contrast, no significant differences were detected in the MUSCLE-MP tissue homogenates of the ileum and colon between control and diabetic groups or even after insulin replacement (Figure 6).

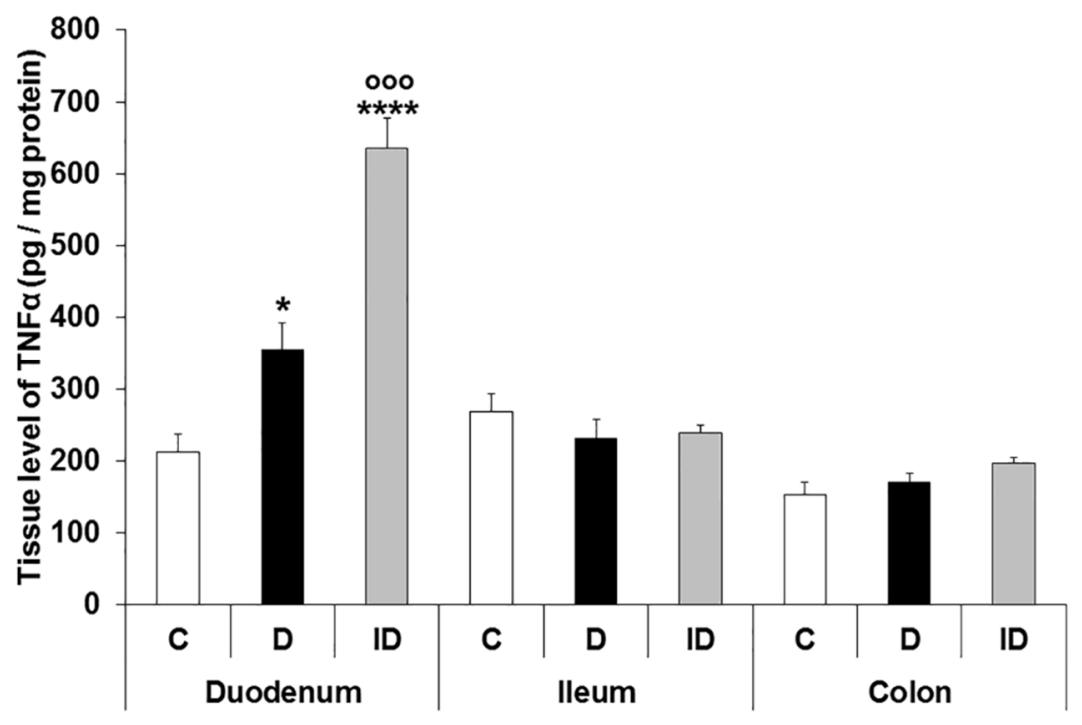

Figure 6. The tissue level of TNF $\alpha$ in the homogenates of intestinal smooth muscle layers, including the myenteric plexus, from the different gut segments of control, diabetic and insulin-treated diabetic rats. The tissue level of $\mathrm{TNF} \alpha$ was markedly increased in the duodenum of diabetic animals, which was further enhanced in the insulin-treated diabetics. Data were expressed as means \pm SEM. ${ }^{*} p<0.05 ;{ }^{* * * *} p<0.0001$ (relative to the controls), ${ }^{\text {ooo }} p<0.001$ (between diabetics and insulin-treated diabetics). C—controls; D—diabetics; ID—insulin-treated diabetics. 
On the other hand, in the MUC-SUBMUC-SP samples of diabetic rats, the TNF $\alpha$ level was unchanged in the duodenum, while significantly decreased in the ileum and colon relative to controls $(6.1 \pm 1.08$ vs. $15.37 \pm 0.47$ in the ileum, $p<0.01 ; 6.18 \pm 0.65$ vs. $15.36 \pm 0.79$ in the colon, $p<0.01$ ) and (Figures 7 and S3).

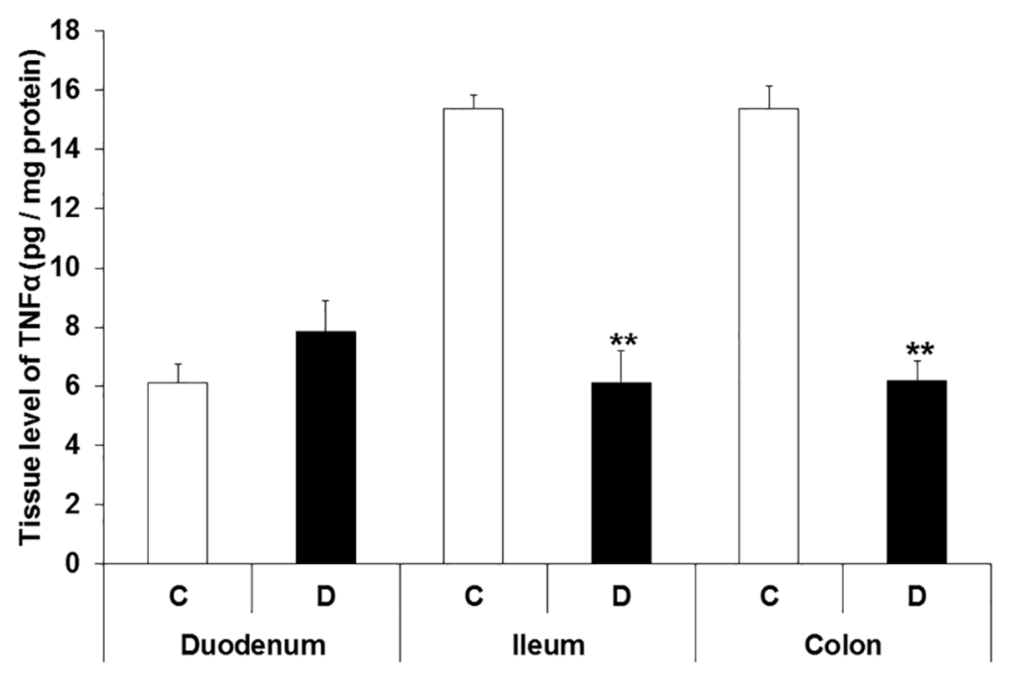

Figure 7. The tissue level of TNF $\alpha$ in the homogenates of mucosa and submucosa, including submucous plexus, from the different gut segments of control and diabetic rats. The level of TNF $\alpha$ was the lowest in the tissue homogenates from the duodenum of controls, while it was more than twice as high in the distal part of the gastrointestinal tract. A statistically significant decrease was observed in TNF $\alpha$ levels in the tissue homogenates of ileum and colon, but not of the duodenum of diabetic rats. Data were expressed as means \pm SEM. ${ }^{* *} p<0.01$ (between controls and diabetics). C-controls; D-diabetics.

\section{Discussion}

In the present study, a distinct gut region-dependent TNF $\alpha$ induction was revealed in type 1 diabetic rats and segment-specific effects of immediate insulin treatment on TNF $\alpha$ expression was also observed. These findings agreed well with the regionality of diabetic myenteric neuropathy [6] and regional damage of enteric neuronal environment in diabetes [3,38-41]. Moreover, TNF $\alpha$ levels also showed intestinal layer-dependent differences in health and diabetes as confirmed by immunofluorescence, immunogold electron microscopy and ELISA.

In the control state, an increasing tendency of $\mathrm{TNF} \alpha$-labelling gold particle density was observed in myenteric ganglia along the proximo-distal axis of the gut. A three times higher basal density of TNF $\alpha$ gold labels in the colon than in the proximal small intestine meant a great disparity in itself and refers to a more unfavourable baseline environment and prooxidant milieu of the colon [3,42]. Interestingly, in the colonic myenteric ganglia, the number of TNF $\alpha$ gold particles was half of the control value in diabetic rats. Alteration in the endogenous heme oxygenase (HO), expression may have served as a possible explanation of this finding. In the colon, diabetes-related induction of the HO system and an elevated number of HO1-immunoreactive myenteric neurons was demonstrated [39], which may contribute to the decrease in TNF $\alpha$ expression in ganglia of this gut segment. In mixed cultures of adipocytes and macrophages, the induction of $\mathrm{HO} 1$ expression resulted in a decrease in TNF $\alpha$ secretion and production of other inflammatory mediators; therefore, attenuating the inflammatory responses $[43,44]$. Additionally, the silencing of HO1 expression increased TNF $\alpha$ secretion in the same cell culture [43]. Induced HO1 expression also supressed the TNF $\alpha$-mediated inflammatory processes in human alveolar epithelial cells [45]. In the colon of diabetic rats, we showed markedly decreased TNF $\alpha$ levels also in the tissue homogenates of MUC-SUBMUC-SP samples, which may refer to a similar response in the mucosal-submucosal layers of the large intestine. 
In ileal myenteric ganglia, we did not observe any significant alterations in the density of TNF $\alpha$ gold particles between controls and diabetics, despite of the great induction of the HO system here [39]. However, similar to the colon, a robust decrease in the TNF $\alpha$ level was demonstrated in MUC-SUBMUC-SP samples of the diabetic ileum, which may be a result of a mucosal immune response reflecting the enhanced intestinal HO [39] induced by the diabetes-related massive changes in the microbial composition of these distal gut segments [3].

In the myenteric ganglia of duodenum, the density of TNF $\alpha$-labelling gold particles almost doubled in diabetics relative to controls. Increasing the tissue level of TNF $\alpha$ was also confirmed in MUSCLE-MP homogenates prepared from diabetic duodenum, which may derive mainly from the higher amount of intestinal smooth muscle in the homogenates. The most intense fluorescence labelling was also detected in the longitudinal smooth muscle. However, the TNF $\alpha$ level did not change significantly in duodenal MUC-SUBMUC-SP samples of diabetics. Continuing the evaluation of the possible crosstalk between $\mathrm{HO}$ and TNF $\alpha$ expression, it should be noted that according to our earlier finding, the duodenum was the only gut segment, in which the number of HO1- and HO2-immunoreactive neurons did not increase; it remained unchanged in the myenteric ganglia of diabetics [39].

It is known that the expression of different pro-inflammatory cytokines, such as $\mathrm{TNF} \alpha$, is under an extraordinarily complex regulation [46,47], and the host-microbial interactions, are crucial in this process [48-50]. In a recent study [4], striking differences were revealed in the mucosa-associated duodenal microbiota of diabetic rats. Diabetic duodenal samples were characterized by a massive invasion of the genus Mycoplasma (14\%), while this invasion was not detected in control samples at all. Mycoplasma species are involved in several diseases affecting different organs in patients, and they definitely affect TNF $\alpha$ production. For instance, in children with pneumonia, Mycoplasma infection increases the serum concentration of TNF $\alpha$ that is in correlation with the severity of the disease [51-53]. Mycoplasmas markedly enhance TNF $\alpha$ production in cultured astrocytes [54]. Moreover, mycoplasmas differently trigger the innate immune responses of various antigen presenting cells; they activate strong TNF responses in monocytes, induce B-cells, but poorly affect the TNF expression of dendritic cells [55]. Enteric neurons are also capable of producing different cytokines such as TNF $\alpha$ or interleukins in response to lipopolysaccharide $[18,56]$, suggesting the possibility of the enteric nervous system to initiate defence against pathogenic stimuli $[57,58]$.

However, TNF $\alpha$ has a dual role in cell survival/cell death via different signalling pathways depending on its receptors, TNFR1 and TNFR2 [59]. Whereas TNFR1 is mainly involved in inflammation and neurodegenerative processes, TNFR2 contributes to cell regeneration and neuroprotection $[17,20,59]$. Since in the duodenum of diabetic rats the total number of myenteric neurons remained unchanged [6], we presumed that an increased duodenal TNF $\alpha$ expression may have participated in neuroprotection here. Naturally, further experiments are needed to analyse the TNFR distribution and TNF $\alpha$ signalling in different gut segments for the evaluation of the TNF $\alpha$ effects on enteric neurons.

Immediate insulin treatment did not result in protection against diabetes-related alterations of TNF $\alpha$ expression in any of the gut segments. Moreover, it triggered a great increase in the TNF $\alpha$ level in MUSCLE-MP homogenates relative to both diabetic and control groups. According to literature data, increased amount of TNF $\alpha$ indicates macrophage-induced insulin resistance of the skeletal muscle [60], cerebral insulin resistance in Alzheimer's disease [61] and it inhibits the effect of insulin on glucose uptake and storage [62,63].

As we mentioned earlier, the tissue level of TNF $\alpha$ showed an intestinal layer-dependent concentration even in physiological conditions. The MUSCLE-MP samples displayed orders of magnitude higher TNF $\alpha$ concentration than MUC-SUBMUC-SP homogenates in controls. A similar tendency was observed in the distal colon of mice, where the myenteric TNF $\alpha$ level was multiple times higher than those of the mucosa [64]. The robust difference in TNF $\alpha$ levels between the different layers of the gut wall supports our previous finding that the myenteric 
plexus is more vulnerable to oxidative stress than submucous ganglia [5]. Furthermore, it suggests a sensitive regulatory role for TNF $\alpha$ in microbiota neuro-immune crosstalk.

\section{Conclusions}

In conclusion, the present study demonstrated that chronic hyperglycaemia affects the expression of TNF $\alpha$ in a strictly regional and intestinal layer-dependent manner and it contributes to the region-specific damage of myenteric neurons and their environment in rats with type 1 diabetes. TNF $\alpha$ as a potential therapeutic target has long been in the focus of medical research [60-63]. However, to draw functional conclusions or medical consequences from these findings, further regional investigations involving other elements of TNF signalling pathways are needed.

Supplementary Materials: The following are available online at https:/ / www.mdpi.com/article/10.3 390/cells10092410/s1, Figure S1: Datasheet of TNF $\alpha$ antibody, Figure S2: Representative fluorescent micrograph of a paraffin section of myenteric ganglia from the ileum of a control rat showing negative control by omitting the primary antibodies against TNF $\alpha$ (green) and $\mathrm{HuCD}$ (red). Fluorescent mounting medium containing DAPI was applied for better visualization of the structure. LM-longitudinal smooth muscle layer, CM-circular smooth muscle layer, arrow-myenteric ganglia. Scale: $10 \mu \mathrm{m}$, Figure S3: Representative fluorescent micrographs of paraffin sections of mucosal layers originated from the colon of a control (a) and diabetic (b) rat after TNF $\alpha$ fluorescent immunohistochemistry. Scale bar: $100 \mu \mathrm{m}$.

Author Contributions: Conceptualization, N.B. and M.B.; methodology, Z.S., J.B. and M.B.; validation, J.B. and Z.S.; investigation, N.B., A.a.D., D.M., B.P.B. and L.C.; writing-original draft preparation, N.B.; writing-review and editing, M.B.; visualization, A.a.D., D.M. and L.C.; supervision, M.B.; funding acquisition, N.B. All authors have read and agreed to the published version of the manuscript.

Funding: This research was funded by the Hungarian National Research, Development and Innovation Fund projects, grant number GINOP-2.3.3-15-2016-00006; Hungarian NKFIH fund project, grant number FK131789 (to N.B.); János Bolyai Research Scholarship of the Hungarian Academy of Sciences (to N.B.) and New National Excellence Program of the Ministry for Innovation and Technology from the source of the National Research, Development and Innovation Fund, No. ÚNKP-20-5 (to N.B.).

Institutional Review Board Statement: The principles of the National Institutes of Health (Bethesda, MD, USA) guidelines and the EU directive 2010/63/EU for the protection of animals used for scientific purposes were strictly followed and all the experiments were approved by the National Scientific Ethical Committee on Animal Experimentation (National Competent Authority), with the license number XX/1636/2019.

Informed Consent Statement: Not applicable.

Data Availability Statement: Available upon request.

Acknowledgments: We thank Erika Németh and Katalin Arany for the excellent technical assistance.

Conflicts of Interest: The authors declare no conflict of interest. The funders had no role in the design of the study; in the collection, analyses, or interpretation of data; in the writing of the manuscript or in the decision to publish the results.

\section{References}

1. Burns, A.J.; Pachnis, V. Development of the enteric nervous system: Bringing together cells, signals and genes. Neurogastroenterol. Motil. 2009, 21, 100-102. [CrossRef]

2. Brown, H.; Esterhazy, D. Intestinal immune compartmentalization: Implications of tissue specific determinants in health and disease. Mucosal Immunol. 2021, 1-12. [CrossRef]

3. Wirth, R.; Bodi, N.; Maroti, G.; Bagyanszki, M.; Talapka, P.; Fekete, E.; Bagi, Z.; Kovacs, K.L. Regionally distinct alterations in the composition of the gut microbiota in rats with streptozotocin-induced diabetes. PLoS ONE 2014, 9, e110440. [CrossRef]

4. Wirth, R.; Bódi, N.; Szalai, Z.; Chandrakumar, L.; Maróti, G.; Kovács, K.L.; Bagi, Z.; Mezei, D.; Balázs, J.; Bagyánszki, M. Perturbation of the mucosa-associated anaerobic gut microbiota in streptozotocin-induced diabetic rats. Acta Biol. Szeged. 2021, 65, 75-84. [CrossRef] 
5. Bodi, N.; Bagyanszki, M. Diabetic enteric neuropathy: Imbalance between oxidative and antioxidative mechanisms. In Diabetes: Oxidative Stress and Dietary Antioxidants, 2nd ed.; Preedy, V.R., Ed.; Academic Press: Cambridge, MA, USA, 2020; Volume 3, pp. 25-33.

6. Izbeki, F.; Wittman, T.; Rosztoczy, A.; Linke, N.; Bodi, N.; Fekete, E.; Bagyanszki, M. Immediate insulin treatment prevents gut motility alterations and loss of nitrergic neurons in the ileum and colon of rats with streptozotocin-induced diabetes. Diabetes Res. Clin. Pract. 2008, 80, 192-198. [CrossRef] [PubMed]

7. Bodi, N.; Szalai, Z.; Chandrakumar, L.; Bagyanszki, M. Region-dependent effects of diabetes and insulin-replacement on neuronal nitric oxide synthase- and heme oxygenase-immunoreactive submucous neurons. World J. Gastroenterol. 2017, 23, 7359-7368. [CrossRef] [PubMed]

8. Yarandi, S.S.; Srinivasan, S. Diabetic gastrointestinal motility disorders and the role of enteric nervous system: Current status and future directions. Neurogastroenterol. Motil. 2014, 26, 611-624. [CrossRef] [PubMed]

9. Klinge, M.W.; Sutter, N.; Mark, E.B.; Haase, A.M.; Borghammer, P.; Schlageter, V.; Lund, S.; Fleischer, J.; Knudsen, K.; Drewes, A.M.; et al. Gastric Emptying Time and Volume of the Small Intestine as Objective Markers in Patients with Symptoms of Diabetic Enteropathy. J. Neurogastroenterol. Motil. 2021, 27, 390-399. [CrossRef] [PubMed]

10. Caputi, V.; Popov, J.; Giron, M.C. Gut Microbiota as a Mediator of Host Neuro-Immune Interactions: Implications in Neuroinflammatory Disorders. Mod. Trends Psychiatry 2021, 32, 40-57. [CrossRef]

11. Chandrasekharan, B.; Jeppsson, S.; Pienkowski, S.; Belsham, D.D.; Sitaraman, S.V.; Merlin, D.; Kokkotou, E.; Nusrat, A.; Tansey, M.G.; Srinivasan, S. Tumor necrosis factor-neuropeptide Y cross talk regulates inflammation, epithelial barrier functions, and colonic motility. Inflamm. Bowel Dis. 2013, 19, 2535-2546. [CrossRef]

12. Ruder, B.; Atreya, R.; Becker, C. Tumour Necrosis Factor Alpha in Intestinal Homeostasis and Gut Related Diseases. Int. J. Mol. Sci. 2019, 20, 1887. [CrossRef] [PubMed]

13. Vanamee, E.S.; Faustman, D.L. Structural principles of tumor necrosis factor superfamily signaling. Sci. Signal. 2018, 11. [CrossRef]

14. Aggarwal, B.B.; Kohr, W.J.; Hass, P.E.; Moffat, B.; Spencer, S.A.; Henzel, W.J.; Bringman, T.S.; Nedwin, G.E.; Goeddel, D.V.; Harkins, R.N. Human tumor necrosis factor. Production, purification, and characterization. J. Biol. Chem. 1985, 260, $2345-2354$. [CrossRef]

15. Parameswaran, N.; Patial, S. Tumor necrosis factor-alpha signaling in macrophages. Crit. Rev. Eukaryot Gene Expr. 2010, 20, 87-103. [CrossRef] [PubMed]

16. Aggarwal, B.B.; Gupta, S.C.; Kim, J.H. Historical perspectives on tumor necrosis factor and its superfamily: 25 years later, a golden journey. Blood 2012, 119, 651-665. [CrossRef] [PubMed]

17. Marchetti, L.; Klein, M.; Schlett, K.; Pfizenmaier, K.; Eisel, U.L. Tumor necrosis factor (TNF)-mediated neuroprotection against glutamate-induced excitotoxicity is enhanced by N-methyl-D-aspartate receptor activation. Essential role of a TNF receptor 2-mediated phosphatidylinositol 3-kinase-dependent NF-kappa B pathway. J. Biol. Chem. 2004, 279, 32869-32881. [CrossRef]

18. Coquenlorge, S.; Duchalais, E.; Chevalier, J.; Cossais, F.; Rolli-Derkinderen, M.; Neunlist, M. Modulation of lipopolysaccharideinduced neuronal response by activation of the enteric nervous system. J. Neuroinflammation 2014, 11, 202. [CrossRef]

19. Barbara, J.A.; Van Ostade, X.; Lopez, A. Tumour necrosis factor-alpha (TNF-alpha): The good, the bad and potentially very effective. Immunol. Cell Biol. 1996, 74, 434-443. [CrossRef]

20. Fischer, R.; Maier, O. Interrelation of oxidative stress and inflammation in neurodegenerative disease: Role of TNF. Oxid. Med. Cell Longev. 2015, 2015, 610813. [CrossRef]

21. Nakaizumi, A.; Horie, T.; Kida, T.; Kurimoto, T.; Sugiyama, T.; Ikeda, T.; Oku, H. Nitric oxide potentiates TNF-alpha-induced neurotoxicity through suppression of NF-kappaB. Cell Mol. Neurobiol. 2012, 32, 95-106. [CrossRef]

22. Smith, J.A.; Das, A.; Ray, S.K.; Banik, N.L. Role of pro-inflammatory cytokines released from microglia in neurodegenerative diseases. Brain Res. Bull. 2012, 87, 10-20. [CrossRef] [PubMed]

23. Chen, K.B.; Uchida, K.; Nakajima, H.; Yayama, T.; Hirai, T.; Watanabe, S.; Guerrero, A.R.; Kobayashi, S.; Ma, W.Y.; Liu, S.Y.; et al. Tumor necrosis factor-alpha antagonist reduces apoptosis of neurons and oligodendroglia in rat spinal cord injury. Spine 2011, 36, 1350-1358. [CrossRef] [PubMed]

24. Mir, M.; Asensio, V.J.; Tolosa, L.; Gou-Fabregas, M.; Soler, R.M.; Llado, J.; Olmos, G. Tumor necrosis factor alpha and interferon gamma cooperatively induce oxidative stress and motoneuron death in rat spinal cord embryonic explants. Neuroscience 2009, 162, 959-971. [CrossRef]

25. Kontermann, R.E.; Scheurich, P.; Pfizenmaier, K. Antagonists of TNF action: Clinical experience and new developments. Expert Opin. Drug Discov. 2009, 4, 279-292. [CrossRef]

26. Qiao, Y.C.; Chen, Y.L.; Pan, Y.H.; Tian, F.; Xu, Y.; Zhang, X.X.; Zhao, H.L. The change of serum tumor necrosis factor alpha in patients with type 1 diabetes mellitus: A systematic review and meta-analysis. PLoS ONE 2017, 12, e0176157. [CrossRef]

27. Lechleitner, M.; Koch, T.; Herold, M.; Dzien, A.; Hoppichler, F. Tumour necrosis factor-alpha plasma level in patients with type 1 diabetes mellitus and its association with glycaemic control and cardiovascular risk factors. J. Intern. Med. 2000, 248, 67-76. [CrossRef]

28. Alzamil, H. Elevated Serum TNF-alpha Is Related to Obesity in Type 2 Diabetes Mellitus and Is Associated with Glycemic Control and Insulin Resistance. J. Obes. 2020, 2020, 5076858. [CrossRef] 
29. Swaroop, J.J.; Rajarajeswari, D.; Naidu, J.N. Association of TNF-alpha with insulin resistance in type 2 diabetes mellitus. Indian J. Med. Res. 2012, 135, 127-130. [CrossRef]

30. Akash, M.S.H.; Rehman, K.; Liaqat, A. Tumor Necrosis Factor-Alpha: Role in Development of Insulin Resistance and Pathogenesis of Type 2 Diabetes Mellitus. J. Cell Biochem. 2018, 119, 105-110. [CrossRef]

31. Costagliola, C.; Romano, V.; De Tollis, M.; Aceto, F.; dell'Omo, R.; Romano, M.R.; Pedicino, C.; Semeraro, F. TNF-alpha levels in tears: A novel biomarker to assess the degree of diabetic retinopathy. Mediators Inflamm. 2013, 2013, 629529. [CrossRef] [PubMed]

32. Donate-Correa, J.; Ferri, C.M.; Sanchez-Quintana, F.; Perez-Castro, A.; Gonzalez-Luis, A.; Martin-Nunez, E.; Mora-Fernandez, C.; Navarro-Gonzalez, J.F. Inflammatory Cytokines in Diabetic Kidney Disease: Pathophysiologic and Therapeutic Implications. Front Med. 2020, 7, 628289. [CrossRef]

33. Purohit, S.; Sharma, A.; Zhi, W.; Bai, S.; Hopkins, D.; Steed, L.; Bode, B.; Anderson, S.W.; Reed, J.C.; Steed, R.D.; et al. Proteins of TNF-alpha and IL6 Pathways Are Elevated in Serum of Type-1 Diabetes Patients with Microalbuminuria. Front Immunol. 2018, 9, 154. [CrossRef]

34. Navarro, J.F.; Mora-Fernandez, C. The role of TNF-alpha in diabetic nephropathy: Pathogenic and therapeutic implications. Cytokine Growth Factor Rev. 2006, 17, 441-450. [CrossRef] [PubMed]

35. Cheng, D.; Liang, R.; Huang, B.; Hou, J.; Yin, J.; Zhao, T.; Zhou, L.; Wu, R.; Qian, Y.; Wang, F. Tumor necrosis factor-alpha blockade ameliorates diabetic nephropathy in rats. Clin. Kidney J. 2021, 14, 301-308. [CrossRef] [PubMed]

36. Thomas, H.E.; Darwiche, R.; Corbett, J.A.; Kay, T.W. Evidence that beta cell death in the nonobese diabetic mouse is Fas independent. J. Immunol. 1999, 163, 1562-1569.

37. Lee, L.F.; Xu, B.; Michie, S.A.; Beilhack, G.F.; Warganich, T.; Turley, S.; McDevitt, H.O. The role of TNF-alpha in the pathogenesis of type 1 diabetes in the nonobese diabetic mouse: Analysis of dendritic cell maturation. Proc. Natl. Acad. Sci. USA 2005, 102, 15995-16000. [CrossRef] [PubMed]

38. Bodi, N.; Talapka, P.; Poles, M.Z.; Hermesz, E.; Jancso, Z.; Katarova, Z.; Izbeki, F.; Wittmann, T.; Fekete, E.; Bagyanszki, M. Gut region-specific diabetic damage to the capillary endothelium adjacent to the myenteric plexus. Microcirculation 2012, 19, 316-326. [CrossRef]

39. Chandrakumar, L.; Bagyanszki, M.; Szalai, Z.; Mezei, D.; Bodi, N. Diabetes-Related Induction of the Heme Oxygenase System and Enhanced Colocalization of Heme Oxygenase 1 and 2 with Neuronal Nitric Oxide Synthase in Myenteric Neurons of Different Intestinal Segments. Oxid. Med. Cell Longev. 2017, 2017, 1890512. [CrossRef] [PubMed]

40. Bodi, N.; Mezei, D.; Chakraborty, P.; Szalai, Z.; Barta, B.P.; Balazs, J.; Razga, Z.; Hermesz, E.; Bagyanszki, M. Diabetes-related intestinal region-specific thickening of ganglionic basement membrane and regionally decreased matrix metalloproteinase 9 expression in myenteric ganglia. World J. Diabetes 2021, 12, 658-672. [CrossRef]

41. Jancso, Z.; Bodi, N.; Borsos, B.; Fekete, E.; Hermesz, E. Gut region-specific accumulation of reactive oxygen species leads to regionally distinct activation of antioxidant and apoptotic marker molecules in rats with STZ-induced diabetes. Int. J. Biochem. Cell. Biol. 2015, 62, 125-131. [CrossRef]

42. Sanders, L.M.; Henderson, C.E.; Hong, M.Y.; Barhoumi, R.; Burghardt, R.C.; Carroll, R.J.; Turner, N.D.; Chapkin, R.S.; Lupton, J.R. Pro-oxidant environment of the colon compared to the small intestine may contribute to greater cancer susceptibility. Cancer Lett. 2004, 208, 155-161. [CrossRef] [PubMed]

43. Kim, Y.; Park, Y.; Namkoong, S.; Lee, J. Esculetin inhibits the inflammatory response by inducing heme oxygenase-1 in cocultured macrophages and adipocytes. Food Funct. 2014, 5, 2371-2377. [CrossRef] [PubMed]

44. Namkoong, S.; Sung, J.; Yang, J.; Choi, Y.; Jeong, H.S.; Lee, J. Nobiletin Attenuates the Inflammatory Response Through Heme Oxygenase-1 Induction in the Crosstalk Between Adipocytes and Macrophages. J. Med. Food 2017, 20, 873-881. [CrossRef] [PubMed]

45. Lin, C.C.; Hsiao, L.D.; Cho, R.L.; Yang, C.M. CO-Releasing Molecule-2 Induces Nrf2/ARE-Dependent Heme Oxygenase-1 Expression Suppressing TNF-alpha-Induced Pulmonary Inflammation. J. Clin. Med. 2019, 8, 436. [CrossRef] [PubMed]

46. Kalliolias, G.D.; Ivashkiv, L.B. TNF biology, pathogenic mechanisms and emerging therapeutic strategies. Nat. Rev. Rheumatol. 2016, 12, 49-62. [CrossRef] [PubMed]

47. Varfolomeev, E.; Vucic, D. Intracellular regulation of TNF activity in health and disease. Cytokine 2018, 101, 26-32. [CrossRef]

48. Wang, C.; Li, W.; Wang, H.; Ma, Y.; Zhao, X.; Zhang, X.; Yang, H.; Qian, J.; Li, J. Saccharomyces boulardii alleviates ulcerative colitis carcinogenesis in mice by reducing TNF-alpha and IL-6 levels and functions and by rebalancing intestinal microbiota. BMC Microbiol. 2019, 19, 246. [CrossRef]

49. Wang, Y.; Yin, Y.; Chen, X.; Zhao, Y.; Wu, Y.; Li, Y.; Wang, X.; Chen, H.; Xiang, C. Induction of Intestinal Th17 Cells by Flagellins from Segmented Filamentous Bacteria. Front. Immunol. 2019, 10, 2750. [CrossRef]

50. Locantore, P.; Del Gatto, V.; Gelli, S.; Paragliola, R.M.; Pontecorvi, A. The Interplay between Immune System and Microbiota in Osteoporosis. Mediat. Inflamm. 2020, 2020, 3686749. [CrossRef]

51. Tian, F.; Han, B.; Duan, M. Serum tumor necrosis factor-\&alpha; interleukin -6 and galctin-3 concentrations in children with Mycoplasma pneumoniae pneumonia. Zhongguo Dang Dai Er Ke Za Zhi 2014, 16, 1001-1004.

52. Wang, Y.; Zhang, Y.; Lu, W.; Wang, L. Serum Tumor Necrosis Factor-alpha and Interferon-gamma Levels in Pediatric Mycoplasma pneumoniae Pneumonia: A Systematic Review and Meta-Analysis. Can. Respir. J. 2018, 2018, 8354892. [CrossRef] 
53. Li, G.; Fan, L.; Wang, Y.; Huang, L.; Wang, M.; Zhu, C.; Hao, C.; Ji, W.; Liang, H.; Yan, Y.; et al. High co-expression of TNF-alpha and CARDS toxin is a good predictor for refractory Mycoplasma pneumoniae pneumonia. Mol. Med. 2019, 25, 38. [CrossRef] [PubMed]

54. Brenner, T.; Yamin, A.; Abramsky, O.; Gallily, R. Stimulation of tumor necrosis factor-alpha production by mycoplasmas and inhibition by dexamethasone in cultured astrocytes. Brain Res. 1993, 608, 273-279. [CrossRef]

55. Trueeb, B.S.; Braun, R.O.; Auray, G.; Kuhnert, P.; Summerfield, A. Differential innate immune responses induced by Mycoplasma hyopneumoniae and Mycoplasma hyorhinis in various types of antigen presenting cells. Vet. Microbiol. 2020, $240,108541$. [CrossRef] [PubMed]

56. Burgueno, J.F.; Barba, A.; Eyre, E.; Romero, C.; Neunlist, M.; Fernandez, E. TLR2 and TLR9 modulate enteric nervous system inflammatory responses to lipopolysaccharide. J. Neuroinflammation 2016, 13, 187. [CrossRef]

57. Yoo, B.B.; Mazmanian, S.K. The Enteric Network: Interactions between the Immune and Nervous Systems of the Gut. Immunity 2017, 46, 910-926. [CrossRef] [PubMed]

58. Giuffre, M.; Moretti, R.; Campisciano, G.; da Silveira, A.B.M.; Monda, V.M.; Comar, M.; Di Bella, S.; Antonello, R.M.; Luzzati, R.; Croce, L.S. You Talking to Me? Says the Enteric Nervous System (ENS) to the Microbe. How Intestinal Microbes Interact with the ENS. J. Clin. Med. 2020, 9, 3705. [CrossRef]

59. Gough, P.; Myles, I.A. Tumor Necrosis Factor Receptors: Pleiotropic Signaling Complexes and Their Differential Effects. Front. Immunol. 2020, 11, 585880. [CrossRef]

60. Bu, L.; Cao, X.; Zhang, Z.; Wu, H.; Guo, R.; Ma, M. Decreased secretion of tumor necrosis factor-alpha attenuates macrophagesinduced insulin resistance in skeletal muscle. Life Sci. 2020, 244, 117304. [CrossRef]

61. Clark, I.; Atwood, C.; Bowen, R.; Paz-Filho, G.; Vissel, B. Tumor necrosis factor-induced cerebral insulin resistance in Alzheimer's disease links numerous treatment rationales. Pharmacol. Rev. 2012, 64, 1004-1026. [CrossRef]

62. Rask-Madsen, C.; Dominguez, H.; Ihlemann, N.; Hermann, T.; Kober, L.; Torp-Pedersen, C. Tumor necrosis factor-alpha inhibits insulin's stimulating effect on glucose uptake and endothelium-dependent vasodilation in humans. Circulation 2003, 108, 1815-1821. [CrossRef] [PubMed]

63. Halse, R.; Pearson, S.L.; McCormack, J.G.; Yeaman, S.J.; Taylor, R. Effects of tumor necrosis factor-alpha on insulin action in cultured human muscle cells. Diabetes 2001, 50, 1102-1109. [CrossRef] [PubMed]

64. Patel, B.A.; Fidalgo, S.; Wang, C.; Parmar, L.; Mandona, K.; Panossian, A.; Flint, M.S.; Ranson, R.N.; Saffrey, M.J.; Yeoman, M.S. The TNF-alpha antagonist etanercept reverses age-related decreases in colonic SERT expression and faecal output in mice. Sci. Rep. 2017, 7, 42754. [CrossRef] [PubMed] 